\title{
Correspondence between environmental gradients and summer littoral fish assemblages in low salinity reaches of the Chesapeake Bay, USA
}

\author{
C. Michael Wagner*, Herbert M. Austin \\ Virginia Institute of Marine Science, School of Marine Science, College of William \& Mary, Gloucester Point, Virginia 23062, USA
}

\begin{abstract}
Patterns in the assemblage structure of littoral fishes occupying the gradient between riverine and estuarine ecosystems were revealed through multivariate analysis of 5 annual summer seine surveys in 4 tributary systems of the lower Chesapeake Bay. Catch per unit effort of fishes was quantified and environmental variables measured to characterize assemblage structure and population responses along large-scale $(\mathrm{km})$ environmental gradients. Results of two-way indicator species analysis (TWINSPAN), detrended correspondence analysis (DCA) and detrended canonical correspondence analysis (DCCA) suggested the presence of 4 intergrading assemblages of littoral beach fishes: permanent tidal freshwater, lower tidal freshwater, oligohaline estuary and mesohaline estuary. Littoral fish assemblages were ordered along a large-scale spatial gradient between tidal freshwater and mesohaline river reaches during summer, when relatively stable hydrological conditions create a well-defined salinity gradient. Large-scale distribution of these fishes along the river axis corresponded with salinity (and its correlates) up to the interface, and with structural attributes of the habitat (nearshore sediment grain size, presence of submerged aquatic vegetation, woody debris) in the permanent tidal freshwater river reaches. The permanent tidal freshwater reaches were more riverine in character, and were typified by speciose and relatively stable assemblages dominated by resident secondary division freshwater fishes and the juveniles of several diadromous species. Although the resident fauna is certainly derivative of more upland, non-tidal streams, patterns of association suggest distinct ecological relationships may exist for species co-occurring in tidal freshwater habitats.
\end{abstract}

KEY WORDS: Nekton Estuarine gradient. Tidal freshwater Chesapeake Bay

\section{INTRODUCTION}

Long-term declines in the availability of submerged structural habitats in the deeper waters $(>1 \mathrm{~m}$ ) of the Chesapeake Bay estuary may be precipitating a shift in the distribution of small epifaunal crustaceans and fishes into non-vegetated littoral waters (Ruiz et al. 1993). Accompanying this shift in habitat utilization, changes in the demography of several species may have occurred (Mittelbach 1986, Werner 1986). Given the functional importance of small fishes as both forage and recruits to recreationally and commercially important fisheries, any of these changes may have cascad-

- Present address: University of Georgia, Warnell School of Forest Resources, Athens, Georgia 30602, USA.

E-mail: cmw4213@owl.forestry.uga.edu ing effects throughout the trophic architecture of the estuary and should be carefully evaluated (Carpenter et al. 1985, Posey \& Hines 1991).

The vast majority of research on the distribution of small fishes inhabiting shallow mid-Atlantic estuarine environments has been conducted in the lower and middle reaches of estuaries where salinity is usually greater than $5.0 \%$. Consequently, we currently lack a detailed understanding of the large-scale $(\mathrm{km})$ assemblage structure of these fishes in low salinity environments, particularly tidal freshwater. According to the generally accepted Gaussian model of assemblage structure, these fish populations may exhibit largely independent unimodal responses to complex environmental gradients resulting in a gradual species turnover known as a 'coenocline' (Gleason 1926; Whittaker 1967). Although environmental gradients (partic- 

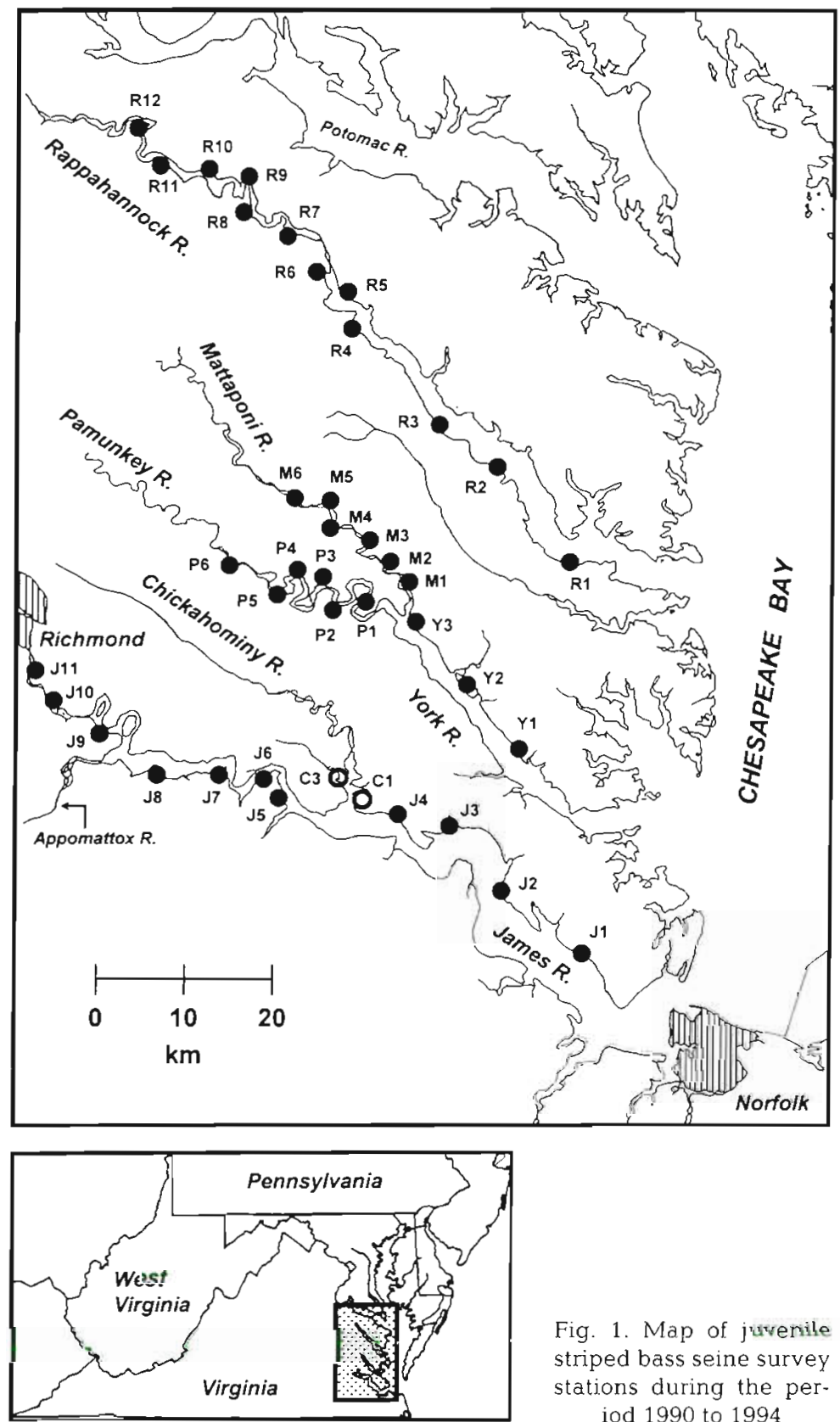

Fig. 1. Map of juvenile striped bass seine survey stations during the period 1990 to 1994

As an extension of the Gaussian model, the family of multivariate techniques based on the reciprocal averaging (RA) algorithm have proven useful for examining complex relationships among multiple environmental gradients and populations (Gauch 1982, Palmer 1993). As pointed out by Coull (1985), such studies are a necessary step toward the formation of causal hypotheses and the progression to experimental, process-oriented study in estuarine systems. Here, we apply RA-based techniques to identify patterns in the assemblage structure of sandy beach fishes in the low salinity reaches of tidal tributaries to the lower Chesapeake Bay. Specifically, we address the following questions: (1) Do well-defined patterns of change in assemblage structure exist? (2) Do these patterns correspond with large-scale environmental gradients? (3) What are the relative importance of various environmental gradients to large-scale assemblage structure in estuarine versus tidal fresh waters?

\section{METHODS}

Study area. The Chesapeake Bay is the largest estuary in the United States, having an area of $6500 \mathrm{~km}^{2}$, a length of $315 \mathrm{~km}$, and mean depth of $8.4 \mathrm{~m}$. The Bay has numerous tributaries which yield a drainage basin surface area to water surface area ratio of $28: 1$. In Virginia, the 3 largest tributaries are the James, Rappahannock and York Rivers, whose combined discharge represents approximately $19 \%$ of the total freshwater inflow to the Bay (Schubel \& Pritchard 1987). These rivers are typified by extensive shoals less than $4 \mathrm{~m}$ deep which vary in width from tens of meters in the upper reaches to more than

ularly those correlated with salinity) clearly influence the distributional patterns of estuarine species along the mid-Atlantic coast (Boesch 1977, Weinstein et al. 1980), the importance of environmental gradients to tidal freshwater assemblages is poorly understood. In a review contrasting tidal freshwater and salt marsh ecosystems, Odum (1988) concluded that while basic ecological structure and processes are the same at both ends of the estuarine gradient, significant differences exist in species diversity, assemblage structure, and in the patterns, rates and end products of many biogeochemical processes.
$1 \mathrm{~km}$ near their mouths. Shorelines in upper reaches are heavily vegetated with vascular shrubs and trees, transitioning into freshwater and salt marshes in the lower tidal freshwater and estuarine reaches,

Water temperatures may reach as high as 28 to $30^{\circ} \mathrm{C}$ in late summer, and river salinities are graded from polyhaline waters $(>18 \%$ ) near the mouth to tidal freshwater $(<0.5 \%)$ below the fall line. Due to fluctuations in the amount of precipitation and runoff, the salinity at a given location varies from monthly to interannual scales, though salinity gradients are stable in late summer. 
Data collection. Since 1967, the Virginia Institute of Marine Science has periodically conducted summer beach seine surveys of the major tidal tributaries to the lower Chesapeake Bay. The primary objective of this monitoring program has been to develop estimates of annual recruitment success for the striped bass Morone saxatilis as input to the fishery management process (Austin et al. 1996). This study used survey data from the 1990 to 1994 sampling period.

Field sampling was conducted during 5 bi-weekly rounds from July to mid-September at 40 fixed stations during daylight hours at or near low tide (Fig. 1). Samples were collected with a $100^{\prime}(30.5 \mathrm{~m})$ long, 4' $(1.22 \mathrm{~m})$ deep, 1/4' $(6.4 \mathrm{~mm})$ bar mesh bagless minnow seine. The seine was set by hand with one end fixed on the beach and the other fully extended, perpendicular to the shoreline (or until a depth of approximately 4 $(1.22 \mathrm{~m})$ was encountered). At stations where depth or current prevents full deployment, the distance from shore of the set was recorded. One tow was made at each station, with an additional replicate tow taken at 18 of the stations for use in the calculation of the striped bass index. Data from the second tow taken at index stations were discarded to make index and nonindex stations comparable. All sample abundances were standardized to a catch per unit effort (CPUE) of $1000 \mathrm{~m}^{2}$ swept area, $\log _{e}(x+1)$ transformed, and reduced to annual means prior to classification and ordination analyses.

Temperature $\left({ }^{\circ} \mathrm{C}\right)$, salinity $(\%)$, dissolved oxygen (mg $\mathrm{I}^{-1} \mathrm{j}$, and $\mathrm{pH}$ were measured at each station with a Hydrolab Reporter ${ }^{\circledast}$ water quality instrument. Sampling time, tidal stage, and general weather and hydrographic conditions were also recorded at the time of each haul. In addition, sediment grain size on the shoals was estimated during the summer of 1997. A modified Wentworth scale was used to classify the dominant nearshore substrate type. Conversations with survey personnel have confirmed that no significant change in dominant bottom type has occurred since the 1990 to 1994 sampling period. Channel width $(\mathrm{m}$; mean lower water), shoal width ( $\mathrm{m}$; measured as distance to the $6^{\prime}(1.83 \mathrm{~m})$ depth contour at mean lower water), and fluvial distance to the bay mouth $(\mathrm{km})$ were also included as covariables. Channel measurements were taken from the most recent US Geological Survey 7.5 minute quadrangle maps.

Multivariate analysis of community structure. The large, sparse arrays of species counts arising from estuarine monitoring programs often do not lend themselves to standard statistical tests based on multivariate normality (Coull 1985, Field et al. 1987). Instead, a valid and often more revealing approach uses informal display methods, such as numerical classification and ordination, based on a biologically appropriate model of similarity between samples. We applied a family of such techniques which utilize the RA algorithm in a procedure which couples indirect and direct gradient analysis (Fig. 2). The biotic data were analyzed first, 'letting the species tell their own story' (Day et al. 1971). The biotic station patterns which arose were then statistically compared to those which arose from a regression model of the biotic data in concert with environmental variables. Such coupling of indirect and direct gradient analysis techniques allows for evaluation of both the agreement between the station patterns, and the degree to which the environmental variables are explanatory of that agreement. Once the strength of these relationships are known, niche dimensions of species along significant environmental gradients may be explored (ter Braak \& Verdonschot 1995).

Before performing the gradient analyses, we made a few decisions about the inclusion of species and stations. To remove any undue effects of rare species on the ordination analyses (Gauch 1982), species occurring in less than $3 \%$ of the samples within a river system were excluded. Only 2 stations were located in the Chickahominy River, a major tributary to the James River (Fig. 1). As this insufficiently sampled the gradient in the Chickahominy, these stations were discarded to maintain focus on large-scale patterns. Finally, as the strength and nature of the estuarine gradient, and resident species pools, vary between rivers, separate analyses were performed on each river system. Stations from the York River were used in analy-

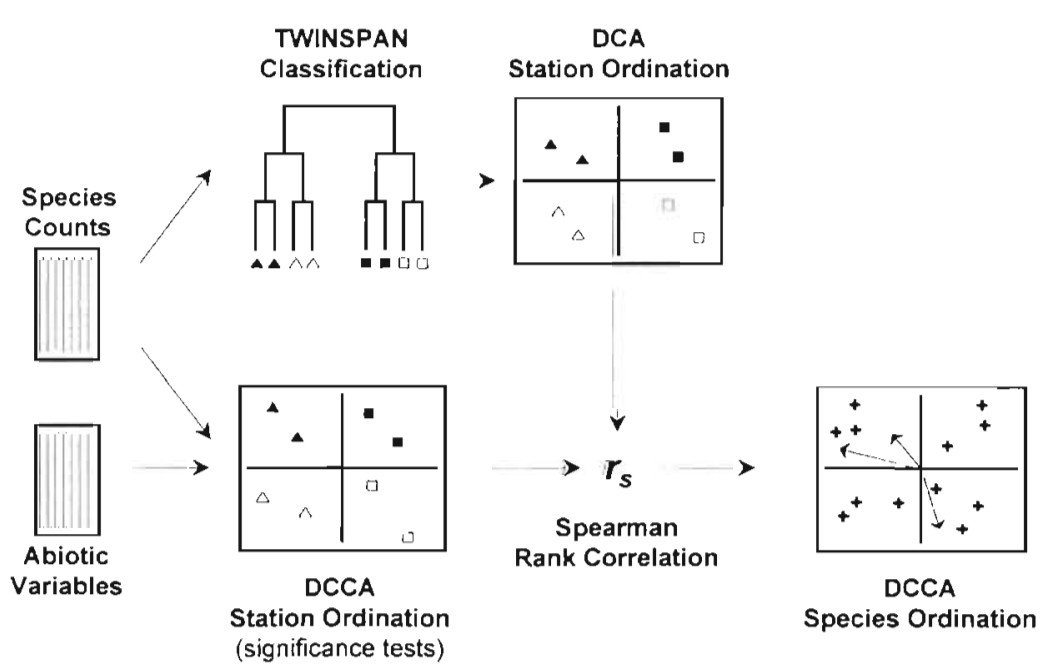

Fig. 2. Schematic diagram of the multivariate analysis 
ses of both of its major tributaries, the Pamunkey and Mattaponi Rivers.

Stations were classified into clusters according to species composition using two-way indicator species analysis (TWINSPAN ill 1979), a dichotomous divisive classification technique. TWINSPAN allows the user to define a number of 'cutlevels' which will split the data for a species into different 'pseudospecies' one for each chosen abundance level. The cutlevels used in this analysis for the CPUE data were $0.1,1,2$, $5,10,20$ and 50 fish per $1000 \mathrm{~m}^{2}$. TWINSPAN also yields 'indicator species' which are most responsible for polarizing the groups at each division level and whose interpretation is not necessarily intuitive. The strength of each division is interpreted from the eigenvalue $(>0.3$ is a strong division, $>0.5$ is a very strong division). A more detailed description of the interpretation of TWINSPAN diagrams may be found in Jongman et. al. (1995).

Stations were then ordinated via detrended correspondence analysis (DCA), a widely used nonlinear eigenvector ordination technique designed for use with large, multi-species data sets (Hill \& Gauch 1980). The DCA axes are synthetic gradients whose length may be related to species turnover via units of standard deviation (SD) in compositional turnover (i.e., 2 $\mathrm{SD} \approx 50 \%$ change, $4 \mathrm{SD} \approx 100 \%$ change ${ }_{i}$ Hill \& Gauch 1980). The 'arch effect' (Gauch 1982) was apparent in the initial correspondence analysis suggesting the need for detrending. Detrending was performed via 26 segments and second-order polynomials using CANOCO vers. 3.12 (ter Braak 1988, 1990). Since the use of polynomial detrending appeared to preserve information on the second. DCA axis (Jongman et al. 1995), we only report those results. Eigenvalue criteria for assessing the importance of the axes are the same as those for the TWINSPAN diagrams.

Statistical associations between assemblage patterns and environmental variables were quantified via detrended canonical correspondence analysis (DCCA), a nonlinear eigenvector ordination technique related to DCA but which constrains station scores to the predicted values which arise from a muitiple regression of the station scores on the environmental variables (ter Braak 1986, 1988). The method extracts synthetic gradients from the environmental variables that maximize the niche separation among species (ter Braak \& Verdonshot 1995). DCCA is an approximation to Gaussian regression under a set of simplifying assumptions, and is robust to violations of those assumptions (ter Braak \& Prentice 1988, Palmer 1993). Significance tests for DCCA models were based on Monte Carlo permutation tests $\left(10^{3}\right.$ permutations) for the sum of all eigenvalues. The significance of relationships between the synthetic gradients and individual environmental vari- ables were evaluated by $t$-tests for the inter-set correlations and the canonical coefficients (ter Braak 1988, 1990). Spearman rank correlation and direct comparison of eigenvalues were used to ascertain the degree to which the species dependent (DCA, weighted average scores) and environment dependent (DCCA, linear combination scores) models accounted for similar variation (Allen \& Peet 1990). The weighted average species scores were used in all DCCA ordination plots and only those environmental variables whose interset correlation coefficient and canonical coefficient were significant at the $p<0.05$ level were included in the plots.

\section{RESULTS}

The general species composition and seasonal cycles of abundance of fishes in nearshore and deeper waters of the Chesapeake Bay are well documented, and the taxa collected during the 1990 to 1994 seine surveys were representative of the available summer fauna. A total of 117004 specimens representing 90 species were collected during the 5 annual surveys, of which 31 were represented by 10 or fewer individuals. The numerous rare species reflected the high summer species diversity of the Chesapeake Bay system relative to other temperate mid-Atlantic estuaries. The complete ichthyofauna of the Bay system (not including many tidal freshwater species) was recently estimated at over 260 species (Murdy et al. 1997). The total number of taxa observed in all collections from a station varied from 20 to 35 species.

Most fishes caught with the seine were small, less than $100 \mathrm{~mm} \mathrm{FL,} \mathrm{including} \mathrm{juveniles} \mathrm{of} \mathrm{relatively} \mathrm{large}$ migratory species and adults of small resident species. Large adult fishes (i.e. $>150 \mathrm{~mm}$ FL), such as striped bass Morone saxatilis, Atlantic croaker Micropogonias undulatus, blue catfish Ictalurus furcatus, and summer flounder Paralichthys dentatus, were captured only occasionally. The Atlantic menhaden Brevoortia tyrannus $(14.2 \%)$, Atlantic silverside Menidia menidia (14.2\%), white perch Morone americana (10.6\%), hogchoker. Trinectes maculatus (9.6\%) and spottail shiner Notropis hudsonius ( $8.3 \%$ ) accounted for $56.9 \%$ of the total catch and generally represented a longitudinal dominance series from mesohaline to tidal freshwater reaches of the rivers. Table 1 provides summary information for the 52 species which met the criteria for retention in the gradient analyses. To aid in the understanding of occurrence patterns, each species was classified into 1 of 7 ecological affinity groups (modified from McHugh 1967) on the basis of known habits of each species within the Chesapeake Bay region as described in Musick (1972), Jenkins \& Burkhead 
Table 1. Summary data and ecological affinity group classification for fish species included in the gradient analysis. TFW: tidal freshwater; marine-frequent: coastal fishes which frequently penetrate the lower bay; estuarine-marine: fishes which spend at least one stage of their cycle within the bay (estuarine dependent); estuarine: fishes which occupy the estuary throughout their life cycle; semi-anadromous: resident fishes which occupy the upper estuary and make limited upstream migrations to spawn; anadromous; principally marine fishes which make significant migrations into freshwater to spawn; freshwater: fishes which occupy freshwater throughout their life cycle. Frequencies calculated for all rivers combined

\begin{tabular}{|c|c|c|c|c|c|c|}
\hline \multirow{2}{*}{$\begin{array}{l}\text { Species } \\
\text { Atlantic menhaden Brevoortia tyrannus }\end{array}$} & \multicolumn{2}{|c|}{$\begin{array}{c}\text { Total caught } \\
\text { (number, \% of total) }\end{array}$} & \multicolumn{2}{|c|}{$\begin{array}{c}\text { Frequency } \\
\text { (TFW, Estuary) }\end{array}$} & \multirow{2}{*}{$\begin{array}{l}\text { Length range } \\
\qquad(\mathrm{FL}, \mathrm{mm}) \\
32-196\end{array}$} & \multirow{2}{*}{$\begin{array}{l}\text { Ecological affinity } \\
\text { group } \\
\text { Estuarine-marine }\end{array}$} \\
\hline & 16564 & 14.2 & 0.02 & 0.21 & & \\
\hline Atlantic silverside Menidia menidia & 16562 & 14.2 & 0.01 & 0.68 & $28-135$ & Estuarine \\
\hline White perch Morone americana & 12353 & 10.6 & 0.79 & 0.54 & $23-280$ & Semi-anadromous \\
\hline Hogchoker Trinectes maculatus & 11238 & 9.6 & 0.65 & 0.45 & $15-159$ & Estuarine \\
\hline Spottail shiner Notropis hudsonius & 9726 & 8.3 & 0.85 & 0.19 & $27-116$ & Freshwater \\
\hline Striped bass Morone saxatilis & 6366 & 5.4 & 0.79 & 0.63 & $25-520$ & Anadromous \\
\hline Gizzard shad Dorosoma cepedianum & 6354 & 5.4 & 0.36 & 0.21 & $26-352$ & Semi-anadromous \\
\hline Spot Leiostomus xanthurus & 4650 & 4.0 & 0.16 & 0.68 & $36-326$ & Estuarine-marine \\
\hline Bay anchovy Anchoa mitchilli & 4530 & 3.9 & 0.12 & 0.48 & $20-95$ & Estuarine \\
\hline Mummichog Fundulus heteroclitus & 3787 & 3.2 & 0.23 & 0.43 & $25-108$ & Estuarine \\
\hline Atlantic croaker Micropogonias undulatus & 3609 & 3.1 & 0.17 & 0.47 & $22-263$ & Estuarine-marine \\
\hline Threadfin shad Dorosoma petenense & 3573 & 3.1 & 0.14 & - & $13-176$ & Semi-anadromous \\
\hline Blueback herring Alosa aestivalis & 2051 & 1.7 & 0.14 & 0.02 & $26-84$ & Anadromous \\
\hline Eastern silvery minnow Hybognathus regius & 2034 & 1.7 & 0.34 & 0.04 & $37-113$ & Freshwater \\
\hline Satinfin shiner Cyprinella analostana & 1882 & 1.6 & 0.59 & 0.06 & $33-105$ & Freshwater \\
\hline Inland silverside Menidia beryllina & 1700 & 1.5 & 0.49 & 0.14 & $25-100$ & Freshwater \\
\hline Banded killifish Fundulus diaphanus & 1210 & 1.0 & 0.36 & 0.08 & $22-117$ & Freshwater \\
\hline Striped killifish Fundulus majalis & 995 & $<1.0$ & 0.03 & 0.26 & $14-155$ & Estuarine \\
\hline White mullet Mugil curema & 846 & $<1.0$ & 0.01 & 0.09 & $38-200$ & Estuarine-marine \\
\hline Channel catfish lctalurus punctatus & 769 & $<1.0$ & 0.34 & 0.12 & $21-519$ & Freshwater \\
\hline White catfish Ameiurus catus & 623 & $<1.0$ & 0.09 & 0.12 & $40-452$ & Freshwater \\
\hline Striped mullet Mugil cephalus & 615 & $<1.0$ & 0.03 & 0.10 & $33-400$ & Estuarine-marine \\
\hline Tessellated darter Etheostoma olmstedi & 602 & $<1.0$ & 0.36 & 0.05 & $28-89$ & Freshwater \\
\hline Yellow perch Perca flavescens & 541 & $<1.0$ & 0.15 & 0.02 & $42-267$ & Freshwater \\
\hline Redbreast sunfish Lepomis auritus & 369 & $<1.0$ & 0.15 & - & $25-175$ & Freshwater \\
\hline American shad Alosa sapidissima & 341 & $<1.0$ & 0.10 & 0.02 & $40-107$ & Anadromous \\
\hline Blue catfish lctalurus furcatus & 340 & $<1.0$ & 0.07 & - & $52-270$ & Freshwater \\
\hline Striped anchovy Anchoa hepsetus & 302 & $<1.0$ & - & 0.18 & $18-100$ & Estuarine-marine \\
\hline Atlantic thread herring Opisthonema oglinum & 265 & $<1.0$ & - & 0.05 & $50-126$ & Marine-frequent \\
\hline Bluegill Lepomis macrochirus & 208 & $<1.0$ & 0.16 & 0.02 & $25-178$ & Freshwater \\
\hline Rough silverside Membras martinica & 195 & $<1.0$ & 0.01 & 0.09 & $38-100$ & Estuarine \\
\hline Silver perch Bairdiella chrysoura & 186 & $<1.0$ & 0.01 & 0.10 & $31-130$ & Estuarine \\
\hline Pumpkinseed Lepomis gibbosus & 183 & $<1.0$ & 0.13 & - & $38-177$ & Freshwater \\
\hline Inshore lizardfish Synodus foetens & 143 & $<1.0$ & - & 0.15 & $53-225$ & Marine-frequent \\
\hline Largemouth bass Micropterus salmoides & 1.42 & $<1.0$ & 0.13 & 0.01 & $45-315$ & Freshwater \\
\hline Southern kingfish Menticirrhus americanus & 140 & $<1.0$ & - & 0.07 & $39-150$ & Marine-frequent \\
\hline Blackcheek tonguefish Symphurus plagiusa & 101 & $<1.0$ & - & 0.10 & $40-132$ & Estuarine \\
\hline Alewife Alosa pseudoharengus & 93 & $<1.0$ & 0.04 & - & $42-92$ & Anadromous \\
\hline Golden shiner Notemigonus chrysoleucas & 83 & $<1.0$ & 0.09 & 0.02 & $45-155$ & Freshwater \\
\hline Atlantic needlefish Strongylura marina & 77 & $<1.0$ & 0.01 & 0.07 & $75-240$ & Estuarine-marine \\
\hline Bluefish Pomatomus saltatrix & 75 & $<1.0$ & - & 0.09 & $50-323$ & Estuarine-marine \\
\hline American eel Anguilla rostrata & 62 & $<1.0$ & 0.08 & 0.02 & $145-614$ & Catadromous \\
\hline Summer flounder Paralichthys dentatus & 59 & $<1.0$ & 0.01 & 0.09 & $46-455$ & Estuarine-marine \\
\hline Weakfish Cynoscion regalis & 57 & $<1.0$ & - & 0.05 & $30-111$ & Estuarine-marine \\
\hline Bluespotted sunfish Enneacanthus gloriosus & 37 & $<1.0$ & 0.03 & - & $25-68$ & Freshwater \\
\hline Rainwater killifish Gambusia affinis & 35 & $<1.0$ & 0.01 & - & $23-47$ & Freshwater \\
\hline Crevalle jack Caranx hippos & 31 & $<1.0$ & - & 0.02 & $35-185$ & Marine-frequent \\
\hline Spotted seatrout Cynoscion nebulosus & 28 & $<1.0$ & - & 0.04 & $30-156$ & Estuarine-marine \\
\hline Smallmouth bass Micropterus dolomieu & 26 & $<1.0$ & 0.03 & - & $48-108$ & Freshwater \\
\hline Spanish mackerel Scomberomorus maculatus & 26 & $<1.0$ & - & 0.03 & $73-150$ & Marine-frequent \\
\hline Common carp Cyprinnus carpio & 16 & $<1.0$ & 0.02 & 0.01 & $70-694$ & Freshwater \\
\hline Oyster toadfish Opsanus tau & 13 & $<1.0$ & - & 0.02 & $59-262$ & Estuarine \\
\hline
\end{tabular}


(1994), and Murdy et al. (1997). Table 2 provides summary habitat and assemblage information for the 38 stations used in the gradient analyses.

\section{Species-station associations}

The first 3 or 4 levels of the TWINSPAN station classifications are summarized in Fig. 3. Further divisions of TWINSPAN groups were not considered as they seemed mainly due to the presence of minor species and did not yield distinct groups within the DCA ordination space (Fig. 4). The first division was very strong in all cases (all eigenvalues $>0.50$ ) and generally coincided with the freshwater interface, separating tidal freshwater stations (left-hand groups) from upper estuary stations (right-hand groups). The indicator species for the primary division were 2 small, ubiquitous resident fishes which overlap at the tidal freshwater interface: the spottail shiner (freshwater), and the Atlantic silverside (saltwater).

The divisions of tidal freshwater stations at the second and higher levels resulted mostly in station groups of differing substrate type. Sandy lower tidal freshwater stations were often characterized by the banded killifish Fundulus diaphanus and the hogchoker, and

Table 2. General station characteristics and taxa collected for the 38 stations included in the gradient analyses. FW: freshwater species; Est: estuarine resident species; Mar: coastal marine and estuarine dependent species; Di: diadromous species; ITB: intertidal beach; SAV: submerged aquatic vegetation

\begin{tabular}{|c|c|c|c|c|c|c|c|}
\hline \multirow{2}{*}{ Station } & \multirow{2}{*}{ Salinity } & \multicolumn{5}{|c|}{ Number of taxa collected } & \multirow{2}{*}{ General station features } \\
\hline & & FW & Est & Mar & Di & Total & \\
\hline R1 & $14.79 \pm 0.65$ & 1 & 9 & 16 & 1 & 27 & Sand ITB, sand substrate \\
\hline $\mathrm{R} 2$ & $13.63 \pm 0.65$ & 2 & 9 & 16 & 2 & 29 & Sand ITB, sand substrate \\
\hline R3 & $10.93 \pm 0.63$ & 3 & 6 & 10 & 2 & 21 & Sand ITB, sand substrate \\
\hline R4 & $5.86 \pm 0.52$ & 6 & 8 & 8 & 2 & 24 & Fringe marsh and sand ITB, sand/silt substrate \\
\hline R5 & $2.92 \pm 0.45$ & 14 & 5 & 7 & 2 & 28 & Marsh and sand ITB, sand/silt substrate \\
\hline R6 & $1.54 \pm 0.31$ & 12 & 5 & 9 & 4 & 30 & Sand ITB, sand bottom \\
\hline R7 & $0.30 \pm 0.13$ & 14 & 6 & 4 & 5 & 29 & Sand/pebble ITB, sand/pebble substrate \\
\hline $\mathrm{R} 8$ & $0.09 \pm 0.07$ & 17 & 5 & 4 & 4 & 30 & Sand ITB, sand/silt substrate \\
\hline R9 & $0.00 \pm 0.00$ & 16 & 2 & 2 & 6 & 26 & Sand/silt ITB, sand/silt substrate \\
\hline R10 & $0.00 \pm 0.00$ & 17 & 3 & 1 & 6 & 27 & Fringe marsh and pebble ITB, pebble substrate \\
\hline $\mathrm{R} 11$ & $0.00 \pm 0.00$ & 21 & 4 & 1 & 6 & 32 & Pebble ITB, pebble substrate \\
\hline $\mathrm{R} 12$ & $0.00 \pm 0.00$ & 19 & 4 & 0 & 3 & 27 & Sand/silt and woody debris ITB, sand/silt bottom \\
\hline Y1 & $16.28 \pm 0.47$ & 1 & 9 & 13 & 2 & 25 & Sand ITB, sand substrate \\
\hline $\mathrm{Y} 2$ & $13.49 \pm 0.43$ & 3 & 11 & 16 & 4 & 34 & Marsh ITB, sand substrate \\
\hline Y3 & $11.92 \pm 0.62$ & 3 & 11 & 17 & 2 & 33 & Sand ITB, sand/silt substrate \\
\hline M1 & $4.60 \pm 0.58$ & 7 & 6 & 10 & 3 & 26 & Sand/silt ITB, sand/silt substrate \\
\hline M2 & $1.77 \pm 0.41$ & 11 & 5 & 8 & 5 & 29 & Fringe marsh and sand/silt ITB, silt/sand substrate \\
\hline M3 & $0.69 \pm 0.17$ & 13 & 5 & 3 & 4 & 25 & Pebble ITB, sand/pebble substrate \\
\hline M4 & $0.24 \pm 0.12$ & 14 & 4 & 3 & 4. & 25 & Sand/pebble ITB, sand/silt substrate \\
\hline M5 & $0.13 \pm 0.11$ & 17 & 3 & 3 & 3 & 26 & Sand ITB, sand/silt substrate, submerged woody debris \\
\hline Mi6 & $0.00 \pm 0.00$ & 26 & 3 & 1 & 5 & 35 & Sand/pebble ITB, sand/pebble substrate, SAV bed \\
\hline $\mathrm{P} 1$ & $3.75 \pm 0.49$ & 8 & 5 & 11 & 5 & 29 & Fringe marsh and sand/silt ITB, sand/silt substrate \\
\hline P2 & $0.87 \pm 0.24$ & 12 & 5 & 5 & 6 & 28 & Sand/pebble ITB, sand/silt substrate \\
\hline P3 & $0.20 \pm 0.08$ & 14 & 3 & 3 & 3 & 23 & Fringe marsh ITB, sand substrate \\
\hline $\mathrm{P} 4$ & $0.05 \pm 0.03$ & 15 & 5 & 3 & 2 & 25 & Sand/pebble ITB, sand/silt substrate \\
\hline P5 & $0.02 \pm 0.01$ & 20 & 3 & 2 & 6 & 31 & Sand/pebble ITB, sand/pebble substrate \\
\hline P6 & $0.00 \pm 0.00$ & 15 & 3 & 0 & 2 & 20 & Sand ITB, sand/pebble substrate \\
\hline J1 & $12.97 \pm 0.90$ & 4 & 7 & 18 & 2 & 31 & Sand ITB, sand substrate \\
\hline J2 & $7.18 \pm 0.48$ & 4 & 6 & 14 & 2 & 26 & Sand ITB, sand substrate \\
\hline J3 & $4.52 \pm 0.35$ & 4 & 4 & 12 & 2 & 22 & Sand ITB, sand substrate \\
\hline J4 & $1.56 \pm 0.23$ & 13 & 4 & 8 & 4 & 29 & Sand ITB, sand substrate \\
\hline J5 & $0.10 \pm 0.05$ & 15 & 5 & 7 & 3 & 30 & Sand ITB, sand/silt substrate, submerged woody debris piles \\
\hline J6 & $0.02 \pm 0.01$ & 14 & 4 & 6 & 4 & 28 & Sand/silt ITB, sand/silt substrate \\
\hline $\mathrm{J} 7$ & $0.02 \pm 0.01$ & 13 & 4 & 3 & 2 & 21 & Sand ITB, sand/silt substrate, submerged woody debris piles \\
\hline J8 & $0.02 \pm 0.01$ & 17 & 4 & 1 & 4 & 26 & Sand ITB, sand/silt substrate \\
\hline J9 & $0.02 \pm 0.01$ & 16 & 1 & 1 & 5 & 24 & Sand/clay ITB, sand/clay substrate \\
\hline $\mathrm{J} 10$ & $0.02 \pm 0.01$ & 16 & 2 & 2 & 4 & 24 & Sand/silt ITB, silt/sand substrate \\
\hline $\mathrm{J} 11$ & $0.02 \pm 0.01$ & 16 & 1 & 2 & 5 & 24 & Sand/silt ITB, sand/silt substrate \\
\hline
\end{tabular}


were consistently occupied by the juveniles of the widely distributed estuarine-marine spot Leiostomus xanthurus and Atlantic croaker. Upper tidal freshwater stations in the Rappahannock River (Stns R9 to R12) were divided into sandy (R9, R12) and pebble (R10, R11) bottoms, with juvenile yellow perch Perca flavescens, juvenile blue catfish, and the pumpkinseed Lepomis gibbosus serving as primary indicators for the
Fig. 3. Two-way indicator species analysis (TWINSPAN) classifications for stations from each river system (Ra: Rappahannock; Y/M: York-Mattaponi; Y/P: York-Pamunkey; Ja: James). Eigenvalues are shown as small bold numbers below divisions. Large bold numbers represent final groupings of stations which are mapped in the DCA plots. Abbreviations for final groups are: U, upper; L, lower; F, tidal freshwater; Og, Oligohaline; $M$, mesohaline; $S$, sandy substrate; $P$, pebble substrate; $\mathrm{Sp}$, mix of sand and pebble substrate; $S$ s, $\mathrm{mix}$ of sand and silt substrate; $V$, vegetated bottom
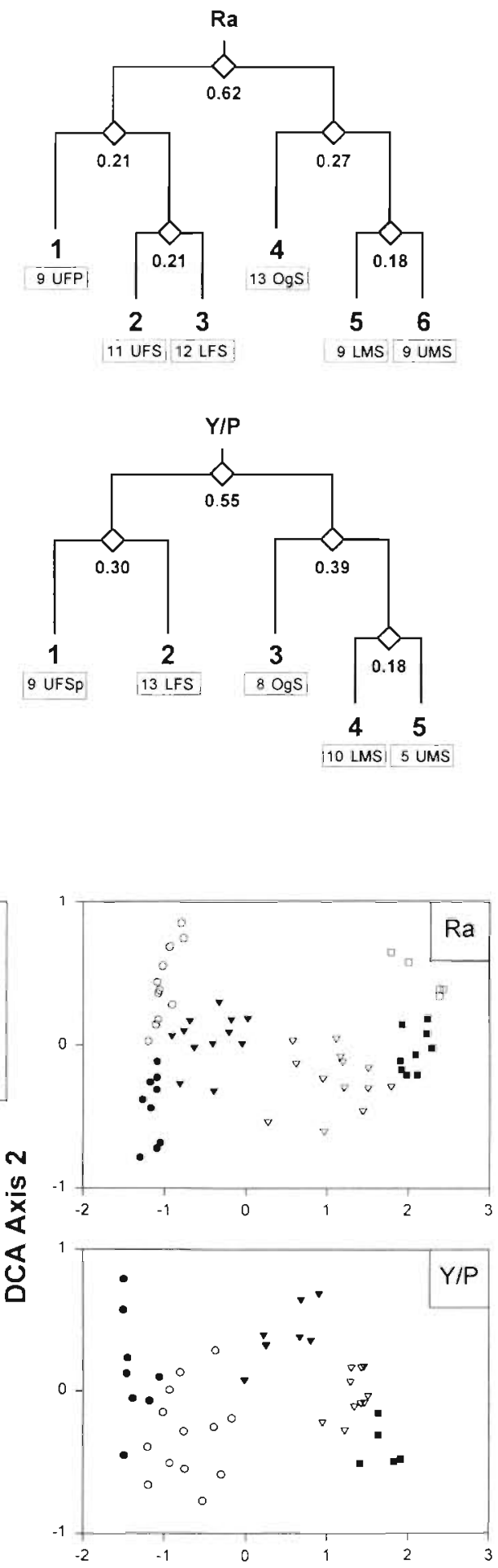
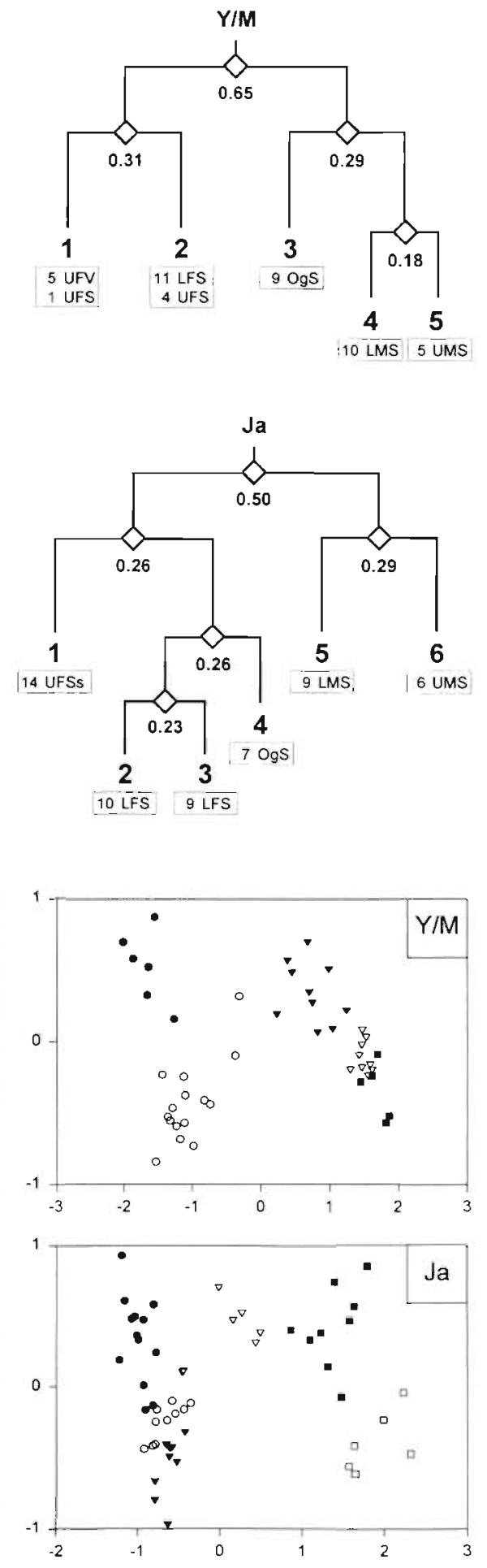

DCA Axis 1
Fig. 4. Detrended correspondence analysis (DCA) ordination plots showing station scores and TWINSPAN groups for the major tributaries to the lower Chesapeake Bay (Ra: Rappahannock Y/M: York-Mattaponi; Y/P: YorkPamunkey; Ja: James) 
Table 3. Direct comparison of detrended correspondence analysis (DCA) and detrended canonical correspondence analysis (DCCA) axes 1 and 2 for stations from each river system via Spearman Rank Correlation ( $\cdots$ p $<$ $0.001)$. DCA scores are weighed average scores and DCCA scores are linear combination scores predicted from the multiple regression

\begin{tabular}{|lcccccc|}
\hline \multirow{2}{*}{ River } & Axis & \multicolumn{3}{c}{ Eigenvalue } & \multicolumn{3}{c|}{ Gradient length } & $r_{\text {S }}$ \\
& & DCA & DCCA & DCA & DCCA & \\
\hline Rappahannock & 1 & 0.61 & 0.56 & 3.73 & 2.67 & $0.95 \cdots$ \\
& 2 & 0.13 & 0.10 & 1.64 & 1.27 & $0.66 \cdots$ \\
York-Mattaponi & 1 & 0.63 & 0.61 & 3.88 & 3.71 & $0.96 \cdots$ \\
& 2 & 0.16 & 0.12 & 1.71 & 1.20 & $0.84 \cdots$ \\
York-Pamunkey & 1 & 0.56 & 0.52 & 3.59 & 2.15 & $0.97 \cdots$ \\
James & 2 & 0.13 & 0.12 & 1.85 & 1.32 & $0.72 \cdots$ \\
& 1 & 0.54 & 0.50 & 3.54 & 2.29 & $0.93 \cdots$ \\
& 2 & 0.18 & 0.09 & 2.03 & 1.04 & $0.46 \cdots$ \\
\hline
\end{tabular}

salinity tolerance (e.g. spottail shiner, channel catfish Ictalurus punctatus, gizzard shad Dorosoma cepedianum). Mesohaline stations split at the third division level into lower and upper reaches due primarily to the limited upstream penetration of several frequently occurring low abundance marine species (e.g. Caranx sp., Mugil sp., inshore lizardfish Synodus foetens, Spanish mackerel Scomberomorus maculatus).

Detrended correspondence analysis of stations from each river system produced ordination diagrams characterized by a distinct longitudinal gradient corresponding to the first ordination axis (Fig. 4). Although in general the TWINSPAN groups were well defined, many stations

coarse substrate. Divisions of tidal freshwater stations in the Mattaponi and Pamunkey Rivers revealed a similar pattern of separating upper from lower tidal freshwater stations with increasing substrate coarseness upstream. The Mattaponi classification was strongly polarized by collections from Stn M6, the only station with beds of submerged aquatic vegetation (SAV). Though not sampled in previous years, SAV at M6 in 1997 was dominated by wild celery Vallisneria americana and the complex alga Nitella flexilis (Charophyceae). Conversations with survey personnel suggest this plant assemblage has been stable in composition, though interannual fluctuations in coverage are probable. Abundances of several fishes were high at M6, suggesting that SAV serves as a concentrator for local species; in particular, the tesselated darter Etheostoma olmstedi and several common centrarchids (redbreast sunfish Lepomis auritus, largemouth bass Micropterus salmoides, and bluegill Lepomis macrochirus). Only the bluespotted sunfish Enneacanthus gloriosus appeared largely constrained to the SAV beds. The substrate pattern was reversed in the James River, where grain size was less diverse and generally decreased from sandy shores below the confluence with the Appomattox River (Stns J6 to J8) to silty-sand above (Stns J9 to J11).

The divisions of upper estuary stations at the second and higher levels resulted mostly in intergrading assemblages of estuarine and marine taxa which appeared to sort stations along the salinity gradient into oligohaline $(0.5$ to $5.0 \%)$, lower mesohaline $(5.0$ to $10 \%$ ) and upper mesohaline (10.0 to $18.0 \%$ ) groups. All estuarine stations were dominated by euryhaline estuarine-dependent and estuarine-resident species (Atlantic silverside, Atlantic menhaden, spot, Atlantic croaker). Oligohaline stations were distinguished by frequent small catches of freshwater fishes with some in neighboring groups were adjacent, and overall, the ordinations represented a riverine-estuarine continuum. Eigenvalues of the first axis were strong in all cases (Table 3) and suggest the gradient that it represented is highly significant and by far the most important. The ecological distances of 3.5 to 3.9 standard deviation units along the first axis correspond to faunal turnovers of $\sim 88$ to $97 \%$. Faunal turnover rates, as measured by the rate of change along the first DCA axis (Fig. 5), peaked near the tidal freshwater interface (origin of the DCA axes). Eigenvalues of the second axes were low and ecological distances of 1.6 to 2.0 standard deviation units correspond to a faunal turnover of $\sim 41$ to $51 \%$.

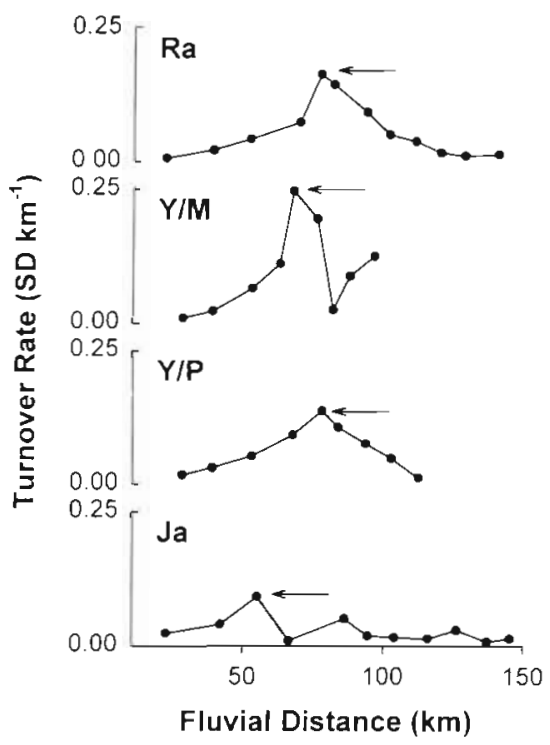

Fig. 5. Longitudinal species turnover rates estimated from the first DCA axis. Distances are measured from the confluence with the Chesapeake Bay. Arrows indicate peaks associated with the tidal freshwater interface 


\section{Species-environment associations}

A direct comparison of environmentally constrained (DCCA) and unconstrained (DCA) station scores is given in Table 3 . Highly significant $(p<0.001)$ Spearman rank correlations indicate that the 2 ordination methods accounted for similar variation. Further support for this interpretation is indicated by the similar gradient lengths and eigenvalues generated by the 2 methods. The generally lower eigenvalues and rank correlations between the second axes of DCA and DCCA probably indicate the importance of unmeasured variables and/or spatial scales.

The DCCA biplot diagrams of environmental variables and species scores (Fig. 6), along with the regression statistics (Table 4) and assignment as TWINSPAN indicator species, permitted interpretation of the general species composition of the putative station groups and major gradients. Salinity and distance to the bay mouth (as covariables of the estuarine gradient) were most important in determining the first canonical axis, and seem to define the main gradient structuring the assemblages in the upper estuary. Measures of habitat size (shoal width and channel width) were variably significant and highly correlated with salinity. However, the truncation of freshwater species scores along the first DCCA axis generally suggest that those variables which continue to decrease in value moving upstream (i.e. distance to the bay mouth, channel width and shoal width) are not controlling the largescale assemblage patterns between regions. The second DCCA axis was generally weak (eigenvalues ranged from 0.09 to 0.12 ) and best represents a gradient in habitat structure (sediment grain size and the presence of SAV) in tidal freshwater. Dissolved oxygen was also significantly negatively correlated with the

Table 4. Results of detrended canonical correspondence analysis for fish assemblages from major tributaries to the lower Chesapeake Bay ( $p<0.05 ; " \mathrm{p}<0.01)$. For all analyses, Monte Carlo probability for significance of the sum of all eigenvalues $(1000$ permutations) is 0.001

\begin{tabular}{|c|c|c|c|c|c|}
\hline Variable & Axis 1 & Axis 2 & Variable & Axis 1 & Axis 2 \\
\hline \multicolumn{3}{|l|}{ Rappahannock River } & \multicolumn{3}{|l|}{ York-Mattaponi River } \\
\hline \multicolumn{3}{|c|}{ Canonical coefficients for environmental variables } & \multicolumn{3}{|c|}{ Canonical coefficients for environmental variabies } \\
\hline Salinity & $0.218^{\circ}$ & 0.065 & Salinity & $0.410^{\cdots}$ & -0.003 \\
\hline Distance to bay mouth & $-0.336 \cdots$ & -0.088 & Distance to bay mouth & $-1.385 \cdots$ & $-2.562 \cdots$ \\
\hline Nearshore grain size & -0.065 & $-0.340^{\cdots}$ & Nearshore grain size & -0.077 & $-0.255^{\cdots}$ \\
\hline \multicolumn{3}{|c|}{ Correiations of environmental variables with axes } & Channel width & $-1.376^{\prime}$ & $-3.170^{\cdots}$ \\
\hline Salinity & $0.909 \cdots$ & 0.004 & Shoal width & $0.719 \cdots$ & $1.477^{\cdots}$ \\
\hline Distance to bay mouth & $-0.933 \cdots$ & 0.066 & Presence of SAV & 0.127 & 1.642 \\
\hline Nearshore grain size & $-0.450^{*}$ & $-0.671^{\cdots}$ & \multicolumn{3}{|c|}{ Correlations of environmental variables with axes } \\
\hline \multicolumn{3}{|c|}{ Summary statistics for ordination axes } & Salinity & $0.867 \cdots$ & -0.116 \\
\hline Eigenvalue & 0.558 & 0.098 & Distance to bay mouth & $-0.938 \cdots$ & 0.148 \\
\hline \multirow{7}{*}{ Species-environment correlation } & 0963 & 0.886 & Nearshore grain size & -0.191 & $0.447 \cdots$ \\
\hline & & & Channel width & $0.700 \cdots$ & -0.192 \\
\hline & & & Shoal width & $0.503^{\cdots}$ & -0.074 \\
\hline & & & Presence of SAV & -0.559 & $0.524 \cdots$ \\
\hline & & & Summary statistics for ordination a & & \\
\hline & & & Eigenvalue & 0.607 & 0.117 \\
\hline & & & Species-environment correlation & 0.982 & 0.885 \\
\hline \multicolumn{3}{|l|}{ York-Pamunkey River } & \multicolumn{3}{|l|}{ James River } \\
\hline \multicolumn{3}{|c|}{ Canonical coefficients for environmental variables } & \multicolumn{3}{|c|}{ Canonical coefficients for environmental variables } \\
\hline Salinity & $0.283 \cdots$ & $0.212^{\circ}$ & Salinity & $0.223 \cdots$ & -0.186 \\
\hline Distance to bay mouth & $-0.784 \cdots$ & $-0.307 \cdots$ & Distance to bay mouth & $-0.279 \cdots$ & 0.131 \\
\hline Nearshore grain size & 0.052 & $0.218 \cdots$ & Nearshore grain size & 0.022 & $-0.114^{\cdot}$ \\
\hline Channel width & $-0.595 \cdots$ & $-0.665 \cdots$ & Shoal width & $0.273^{\cdots}$ & $0.405 \cdots$ \\
\hline Shoal width & $0.295^{\cdots}$ & 0.150 & Dissolved oxygen & -0.016 & $-0.159 \cdots$ \\
\hline \multicolumn{3}{|c|}{ Correlations of environmental variables with axes } & \multicolumn{3}{|c|}{ Correlations of environmental variables with axes } \\
\hline Salinity & $0.864^{\cdots}$ & -0.091 & Salinity & $0.921 \cdots$ & -0.060 \\
\hline Distance to bay mouth & $-0.963^{\cdots}$ & 0.130 & Distance to bay mouth & $-0.933 \cdots$ & 0.145 \\
\hline Nearshore grain size & -0.362 & $0.687^{\cdots}$ & Nearshore grain size & 0.070 & $-0.493 \cdots$ \\
\hline Channel width & $0.768 \cdots$ & -0.266 & Shoal width & $0.926^{\cdots}$ & 0.195 \\
\hline Shoal width & $0.632^{*}$ & -0.222 & Dissolved oxygen & -0.136 & $-0.292^{\circ}$ \\
\hline \multicolumn{3}{|l|}{ Summary statistics for ordination axes } & \multicolumn{3}{|l|}{ Summary statistics for ordination axes } \\
\hline Eigenvalue & 0.523 & 0.097 & Eigenvalue & 0.501 & 0.085 \\
\hline Species-environment correlation & 0.984 & 0.912 & Species-environment correlation & 0.986 & 0.795 \\
\hline
\end{tabular}




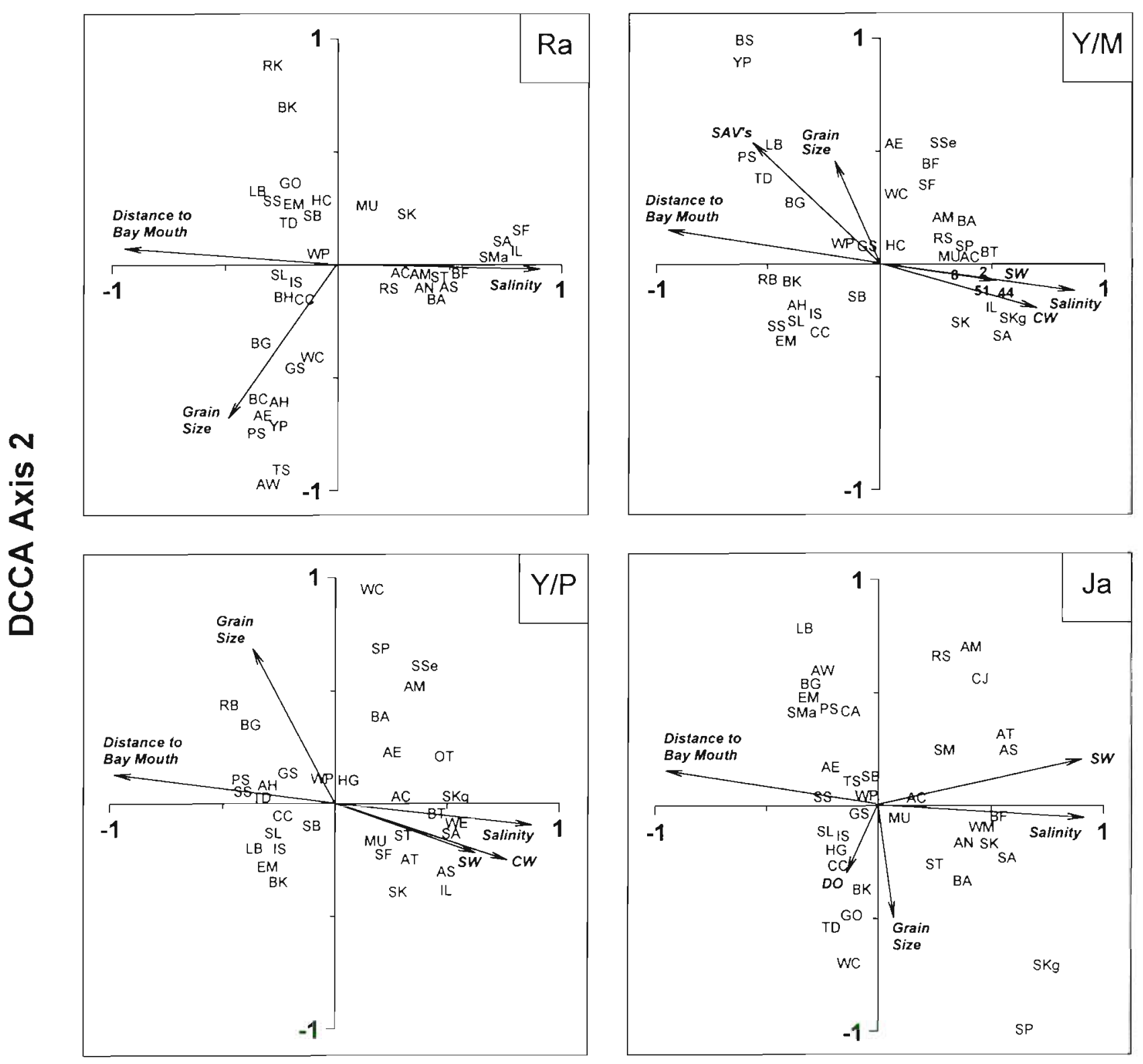

DCCA Axis 1

\begin{tabular}{|c|c|c|c|c|c|c|c|}
\hline $\begin{array}{l}\text { AC } \\
A E \\
A H \\
A M \\
A N \\
A S \\
A T \\
A W \\
\text { AA } \\
\text { BC } \\
B F \\
\text { BG } \\
B H\end{array}$ & $\begin{array}{l}\text { ATL CROAKER } \\
\text { AM. EEL } \\
\text { AM. SHAD } \\
\text { ATL. MENHADEN } \\
\text { ATL. NEEDLEFISH } \\
\text { ATL. SILVERSIDE } \\
\text { ATL THREAD HERRING } \\
\text { ALEWIFE } \\
\text { BAY ANCHOVY } \\
\text { BLUE CATFISH } \\
\text { BLUEFISH } \\
\text { BLUEGILL } \\
\text { BLUEBACK HERRING }\end{array}$ & $\begin{array}{l}\text { BK } \\
\text { BS } \\
\text { BT } \\
\text { CA } \\
\text { CC } \\
\text { CJ } \\
\text { EM } \\
\text { GO } \\
\text { GS } \\
\text { HC } \\
\text { IL } \\
\text { IS } \\
\text { LB }\end{array}$ & $\begin{array}{l}\text { BANDED KILLIFISH } \\
\text { BLUESPOTTED SUNFISH } \\
\text { BLACKCHEEK TONGUEFISH } \\
\text { COMMON CARP } \\
\text { CHANNEL CATFISH } \\
\text { CREVALLE JACK } \\
\text { E SILVERY MINNOW } \\
\text { GOLDEN SHINER } \\
\text { GIZZARD SHAD } \\
\text { HOGCHOKER } \\
\text { INSHORE LIZARDFISH } \\
\text { INLAND SILVERSIDE } \\
\text { LARGEMOUTH BASS }\end{array}$ & $\begin{array}{l}\text { MU } \\
\text { OT } \\
\text { PS } \\
\text { RB } \\
\text { RK } \\
\text { RS } \\
\text { SA } \\
\text { SB } \\
\text { SF } \\
\text { SK } \\
\text { SKg } \\
\text { SL } \\
\text { SM }\end{array}$ & $\begin{array}{l}\text { MUMMICHOG } \\
\text { OYSTER TOADFISH } \\
\text { PUMPKINSEED } \\
\text { REDBREAST SUNFISH } \\
\text { RAINWATER KILLIFISH } \\
\text { ROUGH SILVERSIDE } \\
\text { STRIPED ANCHOVY } \\
\text { STRIPED BASS } \\
\text { SUMMER FLOUNDER } \\
\text { STRIPED KILLIFISH } \\
\text { SOUTHERN KINGFISH } \\
\text { SPOTTAIL SHINER } \\
\text { STRIPED MULLET }\end{array}$ & $\begin{array}{l}\text { SMa } \\
\text { SMb } \\
\text { SP } \\
\text { SS } \\
\text { SSe } \\
\text { ST } \\
\text { TD } \\
\text { TS } \\
\text { WC } \\
\text { WE } \\
\text { WM } \\
\text { WP } \\
\text { YP }\end{array}$ & $\begin{array}{l}\text { SPANISH MACKEREL } \\
\text { SMALLMOUTH BASS } \\
\text { SILVER PERCH } \\
\text { SATINFIN SHINER } \\
\text { SPOTTED SEATROUT } \\
\text { SPOT } \\
\text { TESSELLATED DARTER } \\
\text { THREADFIN SHAD } \\
\text { WHITE CATFISH } \\
\text { WEAKFISH } \\
\text { WHITE MULLET } \\
\text { WHITE PERCH } \\
\text { YELLOW PERCH }\end{array}$ \\
\hline
\end{tabular}

Fiq. 6. Detrended canonical correspondence analysis ordination biplots showing species centroids in relation to environmental variables (SW: shoal. width; CW: channel width). The orthogonal projection of a species centroid onto an environmental vector represents the approximate center the species distribution along that particular environmental gradient 
second DCCA axis in the James River, although its low correlation coefficient $(-0.29)$ renders it suspect. The average dissolved oxygen content in the James River was $6.83 \pm$ $0.09 \mathrm{mg} \mathrm{l}^{-1}$, and the lowest measurement was $3.60 \mathrm{mg} \mathrm{l}^{-1}$, above the generally applied acute stress level of $2.0 \mathrm{mg} \mathrm{l}^{-1}$ (U.S. Environmental Protection Agency 1986).

The centers of distribution, corresponding to modal or peak abundance, of major ecological groups were predictably related to position along the first DCCA axis; the relative abundances of sciaenids, engraulids and marine clupeids were highest in the saline river reaches, whereas cyprinnids, centrarchids, ictalurid catfishes, and anadromous clupeids were primarily distributed above the freshwater interface. Despite marked differences in CPUE of major taxa between fresh and saline waters, there was no relationship between total numerical densities of fishes and salinity (Fig. 7).

The majority of marine and estuarine species fell within an elongated cluster that was closely aligned with the salinity gradient. This cluster appeared to compress along the first axis and smear along the second with increasing proximity to the bay mouth (Rappahannock $\rightarrow$ York/Mattaponi $\rightarrow$ York/Pamunkey $\rightarrow$ James in Fig. 6) indicating a weakening influence of salinity on assemblage structure. The length of the summer salinity gradient generally tends to decrease moving down the bay from the Rappahannock ( 0 to $20 \mathrm{ppt}$ change over $\sim 80 \mathrm{~km}$ fluvial distance) to the James (0 to $20 \mathrm{ppt}$ change over $\sim 40 \mathrm{~km}$ fluvial distance) River and may explain this phenomenon. High-salinity marine species were present in each of the river systems, yet more typically occurred coincident with freshwater species in the James River than in the Rappahannock River at low salinities. The Atlantic silverside, Atlantic menhaden, bay anchovy, and juvenile spot consistently occupied a medial position along the saline portion of the primary gradient (i.e. a value near 0.5 on the first DCCA axis), indicating a wide distribution in all rivers. Three coastal species, the crevalle jack Caranx hippos, white mullet Mugil curema, and striped mullet Mugil cephalus, occurred most frequently in the James River and probably do not make significant penetrations into low salinity waters when such movements would require large excursions from the Atlantic coast.

A distinct group of 3 juvenile fishes were numerically dominant in the tidal freshwater areas immediately upstream of the interface: the striped bass, white perch, and hogchoker. All generally occupied positions near the origin of the DCCA ordination plots, which also coincides with the freshwater interface. The life-

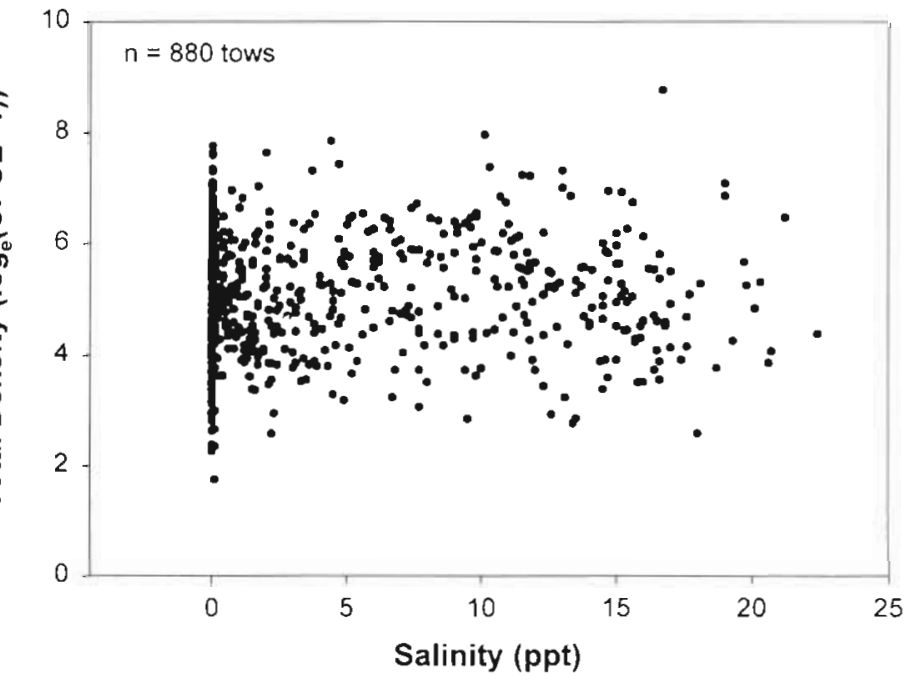

Fig. 7. Numerical fish CPUEs along the salinity gradient. CPUE is given as number of fish per $1000 \mathrm{~m}^{2}$ swept area

histories of these species in the Chesapeake Bay share at least one similarity: each, to varying degrees, displace into increasingly saline, deeper waters with age. With its numerous tributaries, the Chesapeake Bay system incorporates a large area of freshwater interface habitat; a fact which may partially explain the success of these species within the Bay.

Ordination scores for fishes resident in tidal freshwater were widely arrayed along the second DCCA axes and important species could be separated into 2 general associations on the basis of their position in the ordination diagrams. The first association included a group of 3 abundant adult minnows, the spottail shiner, satinfin shiner, and eastern silvery minnow, who were widely distributed, often co-occurred, and were generally clustered in the DCCA space. Aduits of the inland silverside and banded killifish also cooccurred with the minnows. The second group included several subdominant species whose distributions were centered near structural habitat (Rappahannock, Mattaponi and Pamunkey Rivers) or well above the influence of the salt wedge (James River). This group included several common centrarchids (redbreast sunfish, pumpkinseed, largemouth bass), 2 percids (juvenile yellow perch and adult tessellated darter), and juvenile blue catfish (Rappahannock only).

Substrate was the primary abiotic variable coinciding with the large-scale spatial change in assemblage structure in tidal freshwater. Substrate diversity was highest in the Rappahannock River, where pebble bottom (Group 1) was clearly separated from sandy bottom (Groups 2 and 3) in the DCA station ordination. Substrate diversity was less in the York River tributaries, and low in the James River. The yellow perch 
appeared particularly sensitive to substrate diversity, with the largest catches (and position in the DCCA plots) associated with pebble bottom in the Rappahannock River and the presence of SAV in the Mattaponi River. In the lower tidal freshwater reach of the James River 2 groups of stations arose which were not clearly associated with the measured environmental variables (Fig. 3, Groups 2 and 3). However, 8 of the 10 stations in Group 2 were collections taken from J5 and J7, sites with close proximity to submerged piles of woody debris, which may represent an important unmeasured habitat.

\section{DISCUSSION}

\section{Community patterns}

Littoral fish assemblages of the 3 major tributaries to the lower Chesapeake Bay exhibited a strong pattern of longitudinal transition between the upper estuary and permanent tidal freshwater river reaches. This coenocline is similar to patterns observed in other temperate and tropical zone coastal faunas (Weinstein et al. 1980, Rogers et al. 1984, Smith et al. 1984, Felley 1987, Peterson \& Ross 1991, Winemiller \& Leslie 1992), and is characterized by a series of species supplements and replacements in successive downstream locations. Fish assemblages generally grade smoothly into each other with one notable exception; the freshwater interface is a boundary with a markedly increased rate of species turnover. Distinct patterns in the assemblage structure of littoral fishes involving different species associations were clarified by plots of species DCCA centroids. Furthermore, projection of these centroids onto environmental vectors reflected large-scale changes in assemblage structure that coincided with abiotic environmental gradients. While estuarine fish populations in the Chesapeake Bay are known to undergo large interannual fluctuations in abundance (Houde \& Rutherford 1993), affiliations between species' abundance modes and large-scale environmental gradients during summer appear stable from year to year. Results of the classification and ordination analyses suggest the presence of 4 general assemblages of littoral fishes corresponding to position along the primary upper estuary-riverine gradient: mesohaline estuary, oligohaline estuary, lower tidal freshwater near the interface, and permanent tidal freshwater.

\section{Upper estuary}

Small estuarine-resident, estuarine-dependent and marine fishes were ordered along a large-scale spatial gradient between middle and upper estuarine reaches during summer, when relatively stable hydrological conditions create a well-defined salinity gradient in these Chesapeake Bay tributaries (Schubel \& Pritchard 1987). Salinity gradients are often conspicuous in estuaries, and have been likened to a 'physiological sieve' (Remmert 1983) which may order habitats from benign to harsh with respect to individual tolerances (Peterson \& Ross 1991). Numerous models of large-scale species distribution with relation to salinity have been described (e.g. the Venice System), each suggesting longitudinal series of distinct but intergrading species assemblages. Other processes such as physical transport (e.g. estuarine circulation) and biotic interactions (competition and predation) have not been ruled out (Ross \& Epperly 1985), though the latter probably only fine-tune spatial distributions on a local scale (Menge \& Olson 1990).

Previous estuarine studies differ in their estimation of the importance of salinity gradients to the distribution of estuarine fishes in mid-Atlantic waters (Weinstein et al. 1980, Rogers et al. 1984, Rozas \& Hackney 1984, Bulger et al. 1993). These disagreements have been attributed to seasonal alterations in large-scale gradients, and the integration of sequential recruitment of species throughout the year. Rakocinski et al. (1992) demonstrated that salinity gradients are important during periods of relative hydrological stability (i.e. summer). The results of this study indicate that when salinity gradients are stable, the degree of overlap between adjacent assemblages of estuarine and marine fishes is also dictated by the physical strength of the gradient. When physiological systems are stressed, fishes often employ behavioral adjustments to overcome the increased metabolic costs associated with unfavorable environments (Pitcher 1993, Werner \& Anholt 1993). However, when the exposure to such stress may be controlled via residence time, the tendency for highly mobile organisms to penetrate physiologically unfavorable environments in order to gain access to some other resource (e.g. food) may increase. Therefore, distance phenomena (i.e. fluvial distance of an individual from its most favorable habitat) interacts with salinity tolerances and preferences to dictate the modal abundance of a highly mobile marine fishes, and consequently assemblage structure, within the estuary

Tidal freshwater interface

The tidal freshwater interface is the region of greatest physico-chemical complexity in the estuary and. historically, has received little attention from marine and freshwater scientists alike (Odum 1988). Conse- 
quently, well-documented models for spatial assemblage structure have arisen for non-tidal rivers and streams (Schlosser 1987, Rahel \& Hubert 1991) and high salinity estuarine $(>10 \%$ ) environs (Weinstein et al. 1980, Peters \& Cross 1992), with little in between. The freshwater interface zone is a region of sharp transition in the physical and biotic environment where saline and freshwater meet and deposition of the major portion of the alluvial sediment load takes place. An incipient stress point associated with salinities between 0 and 2 ppt has been described which may serve as a barrier to the egress of species ill-adapted to hypertonic environments (Deaton \& Greenberg 1986). The rate of species turnover in all of the rivers peaked in this salinity range, and, in general, marine species made larger forays across the interface than did freshwater species.

The results of this study indicate that juveniles of a few fishes, particularly the striped bass, white perch, and hogchoker may preferentially occupy the shallow waters at and above the tidal freshwater interface. This region has been associated with the 'turbidity maximum' or 'entrapment' zone, an area of the lower estuary where the hydrodynamics entrain suspended material resulting in higher particle concentrations than in waters both landward and seaward. Two contrasting perspectives on the biological role of the turbidity maximum zone (TMZ) have arisen: the first being that it is a zone of stress and mortality for the plankton community (Dodson et al. 1989), the second that it is a biologically productive area with a complex, structured food web (Barclay \& Knight 1981). Recent evidence suggests the TMZ may represent a zone of enhanced recruitment success for larval fishes in the Chesapeake Bay, particularly the striped bass and white perch (Boynton et al. 1997).

\section{Permanent tidal freshwater}

The tidal freshwater river reach is different from riverine habitats, mainly due to tidally induced physical processes such as prolonged residence time of the water, oscillating water levels, and reversing current velocities and directions (Schuchardt et al. 1993). There appears to be no species specialized for exclusive existence in tidal freshwater reaches of the lower Chesapeake Bay, though the inland silverside is largely constrained to these environs, probably due to the presence of the Atlantic silverside within the estuary (Bengtson 1984). Dominant members of the freshwater fauna were cosmopolitan in distribution, particularly the adult cyprinnids, and several sub-dominant but common species served as indicators for particular substrate types. In general, the sandy beach assem- blages were distinct, differing substantially from the adjacent open water assemblage of fishes (Dawson 1992), and from the tidal freshwater marsh assemblage, composed mainly of resident fundulids (Rozas \& Odum 1987b). We believe that these distinct tidal freshwater fish assemblages represent species-specific differences in habitat use rather than gear bias.

The multivariate analysis extracted species which appear to exhibit local preferences for structural habitat. Structural habitat heterogeneity in the form of aquatic vegetation, submerged trees and limbs, coarse detritus and coarse substrate is of ten positively correlated with the local diversity and density of fishes in freshwater environments (Gorman \& Karr 1978, Capone \& Kushlan 1991, Benson \& Magnuson 1992). The effect of substrate was most pronounced in the Rappahannock River ordinations, where several subdominant species seemed to prefer pebble bottom, particularly, juvenile blue catfish and yellow perch, and the pumpkinseed. Substrate grain size was also explanatory of species distributions in the upstream tidal freshwater reaches of the Pamunkey and Mattaponi Rivers. The presence of pebbles on the littoral shoals tended to increase upstream, though this was never the dominant substrate in these rivers. Nevertheless, the presence of several primary division freshwater fishes (mostly centrarchids) were correlated with the increase in mean substrate size (or perhaps diversity), and may indicate proximity to more quiescent riverine-like environments.

The tidal freshwater zone of the James River is characterized by fairly homogenous muddy sediments (Diaz 1989), with sandy shoals becoming more prevalent in the lower freshwater reaches. Nevertheless, upper tidal freshwater stations were partly distinguished by rare catches of freshwater obligate species such as the bluehead chub Nocomis leptocephalus, the smallmouth bass Micropterus dolomieu and the quillback Carpiodes cyprinnus. These catches may reflect minor extirpations from the fall zone near Richmond, VA. The fall zone of the James River has been characterized as an 'ecological island' of upland habitat where many typically upland fishes are caught (Jenkins \& Burkhead 1994). The lower tidal freshwater reach provided some indication that submerged woody debris piles may serve as a fish attractant. Woody debris is known to provide habitat for fish and macroinvertebrates in tidal (Everett \& Ruiz 1993) and non-tidal (Harmon et al. 1986) stream channels.

Only one station had significant SAV beds (M6). The macrofauna associated with SAV have been the subject of extensive study in the estuarine and freshwater environments of the Chesapeake Bay (e.g. Orth et al. 1984, Rozas \& Odum 1988, Sogard \& Able 1991). The submerged plant beds at M6 were heavily used by 
several species of fishes. Since this study is limited to only one station with SAV over a 5 yr period, we can say little about the large-scale spatial patterns in the use of SAV. Nevertheless, certain attributes of the fauna at $M 6$ are notable and congruent with other studies of SAV use in the tributaries to the Chesapeake Bay. For example, juvenile redbreast sunfish and pumpkinseed were much more abundant and frequently captured in the SAV bed versus downstream unvegetated stations. Juvenile centrarchids are known to concentrate in the vegetated littoral zones of lakes (Werner et al. 1977) and tidal freshwater marshes (Rozas \& Odum 1987a). The bluespotted sunfish, a small centrarchid, appeared largely constrained to the SAV beds. Small sunfishes of the genus Enneacanthus are almost invariably associated with vegetation in tidal and non-tidal freshwater swamps where they glean small invertebrates (Lee et al. 1980).

In summary, the rate of change in physical stresses associated with the salinity gradient appear paramount in the large-scale assemblage structure of littoral fishes in the saline portion of these rivers. The tidal freshwater zone, where the complex effects of salinity and estuarine circulation are absent, may be expected to have a homogenous fauna derivative of non-tidal fresh waters. In fact, there is a large-scale patch structure to the nekton which can be correlated with measures of habitat structure. The dominant fauna in both environments are eurytopic, while many sub-dominant but common species appear to serve as indicators for several tidal freshwater habitat types. Overall, the tidal freshwater interface and sandy beaches support numerous adult and juvenile fishes and are an important refuge habitat in the Chesapeake Bay system.

Identification of tidal river zones and their characteristics may provide ecologically meaningful units for river management. Results of our preliminary work strongly suggest that large-scale littoral fish assemblage structure is related to site-level and river-level habitat variation (at least with respect to those species and variables included in the gradient analysis). We expect similar large-scale patterns will arise in other temperate rivers, and suspect a rich hierarchy of ecological coenoses will implicate tidal freshwater river reaches as a specific ecotype with identifiable and unique features. Our work suggest several avenues of continued research including, but not limited to, the following: (1) collection of basic life-history information for the dominant tidal freshwater fishes, particularly the spottail and satinfin shiners; (2) investigation of the extent to which the minnow assemblage shares resources, and how the degree of niche overlap compares to similar assemblages in non-tidal freshwater; and, (3) the role of structural habitat patches (SAVs, woody debris, pebble substrate) in the maintenance of populations and large-scale diversity patterns. The second item is of particular interest as it may shed light on the scale (population vs species) to which competition and predation are selective pressures.

Acknowledgements. Data dtilized in this project were generated via an ongoing contract to monitor the juvenile striped bass populations of the lower Chesapeake Bay funded by the U.S. Fish and Wildlife Service through the Virginia Marine Resources Commission (Sportfish Restoration Project F87R4, Herbert Austin and Deane Estes, co-principal investigators). Sincere gratitude is extended to Donald Seaver and Deane Estes for sharing their historical knowledge of the survey data collection activities. C.M.W. would like to thank Michael Powell and Stuart Ware for their assistance with the CANOCO analyses. We also thank John Christensen, Jim Gelsleichter, Jack Musick and John Olney for their critical reading of this manuscript. This paper is a portion of a master's thesis submitted to the College of William and Mary by the senior author, and is contribution number 2144 of the Virginia Institute of Marine Science.

\section{LITERATURE CITED}

Allen RB, Peet RK (1990) Gradient analysis of forests of the Sangre de Cristo Range, Colorado. Can J Bot 68:193-201 Austin HM, Estes AD, Seaver DM (1996) Annual progress report: estimation of juvenile striped bass in the Virginia portion of the Chesapeake Bay. US Fish Wildl Serv Sportfish Restoration Project F87R4, Jan 1995-Dec 1995. Virginia Institute of Marine Science, Gloucester Point, VA

Barclay WR, Knight AW (1981) The nutritional significance of the distribution of suspended particulate material in the upper San Francisco Bay estuary. In: Cross RD, Williams DL (eds) Proceedings of the National Symposium on Freshwater Inflow to Estuaries, Vol 1. US Dept of the Interior, Washington, DC, FWS/OBS-81/04

Bengtson DA (1984) Resource partitioning by Menidia menidia and Menidia beryllina (Osteichthys: Atherinidae). Mar Ecol Prog Ser 18:21-30

Benson BJ, Magnuson JJ (1992) Spatial heterogeneity of littoral fish assemblages in lakes: relation to species diversity and habitat structure. Can J Fish Aquat Sci 49: 1493-1500

Boesch DF (1977) A new look at zonation of benthos along the estuarine gradient. In: Coull BC (ed) Ecology of marine benthos. University of South Carolina Press, Columbia, p 245-266

Boynton WR, Boicourt W, Brandt S, Hagy J, Harding L, Houde E, Holliday DV, Jech $M$, Kemp WM, Lascara C, Leach SD, Madden AP, Roman M, Sanford L, Smith EM (1997) Interactions between physics and biology in the estuarine turbidity maximum (ETM) of Chesapeake Bay, USA. ICES Annual Meeting, CM 1997/S:11, Session S

Bulger AJ, Hayden BP, Monaco ME, Nelson DM, McCormickRay MG (1993) Biologically-based estuarine salinity zones derived from a multivariate analysis. Estuaries 16:311-322

Capone TA, Kushlan JA (1991) Fish community structure in dry-season stream pools. Ecology 72:983-992

Carpenter SR, Kitchell JF, Hodgson JR (1985) Cascading trophic interactions and lake productivity. BioSci 35 : $634-639$

Coull BC (1985) The use of long-term biological data to generate testable hypotheses. Estuaries 8:84-92

Day JH, Field JG, Montgomery MP (1971) The use of numer- 
ical methods to determine the distribution of the benthic fauna across the continental shelf of North Carolina. J Anim Ecol 40:93-126

Dawson S (1992) Juvenile pelagic fish communities in the Mattaponi and Pamunkey Rivers, Virginia. Unpublished MS Thesis, School of Marine Science, College of William \& Mary, Gloucester Point, VA

Deaton LE, Greenberg MJ (1986) There is no horohalinicum. Estuaries 9:20-30

Diaz RJ (1989) Pollution and tidal benthic communities of the James River estuary, Virginia. Hydrobiologia 180:195-211

Dodson JJ, Dauvin, JC, Ingram RG, D'Anglejan B (1989) Abundance of larval rainbow smelt (Osmerus mordax) in relation to the maximum turbidity zone and associated macroplanktonic fauna of the middle St. Lawrence estuary. Estuaries 12:66-81

Everett RA, Ruiz GM (1993) Coarse woody debris as refuge from predation in aquatic communities: an experimental test. Oecologia 93:475-486

Felley JD (1987) Nekton assemblages in three tributaries to the Calcasieu estuary, Louisiana. Estuaries 10:321-329

Field JG, Green RH, de L Andrade FA, Fresi E, Gros P, McArdle BH, Scardi M, Wartenberg D (1987) Numerical ecology: developments for studying the benthos. In: Legendre $P$, Legendre L (eds) Developments in numerical ecology. NATO ASI series, Vol G14, Springer-Verlag, Berlin, p 485-494

Gauch HG (1982) Multivariate analysis in community ecology. Cambridge University Press, New York

Gleason HA (1926) The individualistic concept of the plant association. Bull Torrey Bot Club 53:7-26

Gorman OT, Karr JR (1978) Habitat structure and stream fish communities. Ecology 59:507-515

Harmon ME, Franklin JF, Swanson JF, Sollins P, Gregory SV (1986) Ecology of coarse woody debris in temperate ecosystems. Adv Ecol Res 15:133-302

Hill MO (1979) TWINSPAN: a FORTRAN program for arranging multivariate data in an ordered two-way table by classification of the individuals and attributes. Ecology and Systematics, Cornell University, Ithaca, NY

Hill MO, Gauch HG (1980) Detrended correspondence analysis: an improved ordination technique. Vegetatio 42:47-58

Houde ED, Rutherford ES (1993) Recent trends in estuarine fisheries: predictions of fish production and yield. Estuaries 16:161-176

Jenkins RE, Burkhead NM (1994) Freshwater fishes of Virginia. American Fisheries Society, Bethesda, MD

Jongman RHG, ter Braak CJF, van Tongeren OFR (1995) Data analysis in community and landscape ecology. Cambridge University Press, New York

Lee DS Gilbert CR, Hocutt CH, Jenkins RE, MCCallister DE, Stauffer JR Jr (1980) A.tlas of North American freshwater fishes. Pub No. 1980-12 of the North Carolina Biological Survey, North Carolina State Museum of Natural History

McHugh JL (1967) Estuarine nekton. In: Lauff GH (ed) Estuaries Pub No. 83, Am Assoc Adv Sci, Washington DC, p 581-620

Menge BA, Olson AM (1990) Role of scale and environmental factors in regulation of community structure. Trends Ecol Evol (TREE) 5:52-57

Mittelbach G (1986) Predator-mediated habitat use: some consequences for species interactions. Environ Biol Fish $16: 159-169$

Murdy EO, Birdsong RS, Musick JA (1997) Fishes of the Chesapeake Bay. Smithsonian Institution Press, Washington DC

Musick JA (1972) Fishes of the Chesapeake Bay and the adja- cent coastal plain. In: Wass ML et al. (eds) A checklist of the biota in Lower Chesapeake Bay. Va Inst Mar Sci, Spec Sci Rept No. 65, p 175-212

Odum WE (1988) Comparative ecology of tidal freshwater and salt marshes. Annu Rev Ecol Syst 19:147-176

Orth RJ, Heck KL Jr, van Montfrans J (1984) Faunal communities in seagrass beds: a review of the influence of plant structure and prey characteristics on predator-prey relationships. Estuaries 7:339-350

Palmer MW (1993) Putting things in even better order: the advantages of canonical correspondence analysis. Ecology 74:2215-2230

Peters DS, Cross FA (1992) What is coastal fish habitat? In: Stroud RH (ed) Stemming the tide of coastal fish habitat loss. Proceedings of the symposium on conservation of coastal fish habitat, Baltimore, MD. Marine recreational fisheries No. 14, National Coalition for Marine Conservation, Inc, Savannah, GA, p 17-22

Peterson MS, Ross ST (1991) Dynamics of littoral fishes and decapods along a coastal river-estuarine gradient. Estuar Coast Shelf Sci 33:467-483

Pitcher TJ(ed) (1993) Behavior of teleost fishes, 2nd edn. Chapman \& Hall, London

Posey MH, Hines AH (1991) Complex predator-prey interactions within an estuarine benthic community. Ecology 72 2155-2169

Rahel FJ, Hubert WA (1991) Fish assemblages and habitat gradients in a Rocky Mountain-Great Plains stream: biotic zonation and additive patterns of community change. Trans Am Fish Soc 120:319-332

Rakocinski CF, Baltz DM, Fleeger JW (1992) Correspondence between environmental gradients and the community structure of marsh-edge fishes in a Louisiana estuary. Mar Ecol Prog Ser 80:135-148

Remmert H (1983) Studies and thoughts about the zonation along the rocky shores of the Baltic. Aquilo Ser Zool 22 121-125

Rogers SG, Targett TE, van Sant SB (1984) Fish-nursery use in Georgia salt-marsh estuaries: the influence of springtime freshwater conditions. Trans Am Fish Soc 113:595-606

Ross SW, Epperly SP (1985) Utilization of shallow estuarine nursery areas by fishes in Pamlico Sound and adjacent tributaries, North Carolina. In: Yáñez-Arancibia A (ed) Fish community ecology in estuaries and coastal lagoons: towards an ecosystem integration. Editorial Universitaria, UNAM-PUAL-ICML, Mexico DF, p 207-232

Rozas LP, Hackney CT (1984) Use of oligohaline marshes by fishes and macrofaunal crustaceans in North Carolina Estuaries 7:21.3-224

Rozas LP, Odum WE (1987a) Fish and macrocrustacean use of submerged plant beds in tidal freshwater marsh creeks. Mar Ecol Prog Ser 38:101-108

Rozas LP, Odum WE (1987b) Use of tidal freshwater marshes by fishes and macrofaunal crustaceans along a marsh stream-order gradient. Estuaries 10:36-43

Rozas LP, Odum WE (1988) Occupation of submerged aquatic vegetation by fishes: testing the roles of food and refuge. Oecologia 77:101-106

Ruiz GM, Hines AH, Posey MH (1993) Shallow water as a refuge habitat for fish and crustaceans in non-vegetated estuaries: an example from Chesapeake Bay. Mar Ecol Prog Ser 99:1-16

Schlosser IJ (1987) A conceptual framework for fish communities in small warmwater streams. In: Matthews WJ, Heins DC (eds) Community and evolutionary ecology of North American stream fishes. University of Oklahoma Press, Norman, p 17-24 
Schubel JR, Pritchard DW (1987) A brief physical description of Chesapeake Bay. In: Majumdar SK, Hall LW, Jr, Austin HM (eds) Contaminant problems and management of living Chesapeake Bay Resources. Pennsylvania Academy of Sciences, printed by Typehouse of Easton, Phillipsburg NJ, p $1-32$

Schuchardt B. Haesloop U, Schirmer M (1993) The tidal freshwater reach of the Weser Estuary: riverine or estuarine? Neth J Aquat Ecol 27:215-226

Smith SM, Hoff JG, O'Neil SP, Weinstein MP (1984) Community and trophic organization of nekton utilizing shallow marsh habitats, York River, Virginia. Fish Bull 82:455-467

Sogard SM, Able KW (1991) A comparison of eelgrass, sea lettuce macroalgae, and marsh creeks as habitats for epibenthic fishes and decapods. Estuar Coast Shelf Sci 33 $501-519$

ter Braak CJF (1986) Canonical correspondence analysis: a new eigenvector technique for multivariate direct gradient analysis. Ecology 67:1167-1.179

ter Braak CJF (1988) CANOCO-a FORTRAN program for canonical community ordination by [partial] [detrended] [canonical] correspondence analysis, principal components analysis and redundancy analysis (Vers 2.1). Report LWA-88-02, Agricultural Mathematics Group, Wageningen

ter Braak CJF (1990) Update notes: CANOCO version 3.1 Agricultural Mathematics Group, Wageningen

Editorial responsibility: Otto Kinne (Editor),

Oldendorf/Luhe, Germany ter Braak CJF, Prentice IC (1988) A theory of gradient analysis. Adv Ecol Res 18:271-31.3

ter Braak C.JF, Verdonschot PFM (1995) Canonical correspondence analysis and related multivariate methods in aquatic ecology. Aquat Sci 57:255-289

US Environmental Protection Agency. (1986) Quality criteria for water 1986. Dissolved oxygen. EPA 440/5-86-001 (NTIS No. PB 86-208253). Office of Water Regulations and Standards, Washington, DC

Weinstein MP, Weiss SL, Walters MF (1980) Multiple determinants of community structure in shallow marsh habitats, Cape Fear River estuary, North Carolina. Mar Biol 58: $227-243$

Wermer EE (1986) Species interactions in freshwater communities. In: Diamond J, Case TJ, (eds) Community ecology. Harper and Row, New York, p 344-357

Werner EE, Anholt BR (1993) Ecological consequences of trade-offs between growth and mortality rates mediated by foraging activity. Am Nat 142:242-272

Werner EE, Hall DJ, Laughlin DR, Wagner DJ, Wilsmann LA, Funk FC (1977) Habitat partitioning in a freshwater community. J Fish Res Bd Can 34:360-370

Whittaker RH (1967) Gradient analysis of vegetation. Biol Rev 42:207-264

Winemiller KO, Leslie MA (1992) Fish assemblages across a complex, tropical freshwater/marine ecotone. Environ Biol Fish $34: 29-50$

Submitted: February 10, 1998; Accepted: August 12, 1998 Proofs received from author(s): January 22, 1999 